\title{
Acquisition Protocol
}

National Cancer Institute

\section{Source}

National Cancer Institute. Acquisition Protocol. NCI Thesaurus. Code C69297.

A protocol for creating images or image-derived measurements. 